\title{
MODERN HOTEL TECNOLOGY TRENDS FOR HOSPITALITY INDUSTRY
}

\author{
Anna Perepelytsia \\ Senior Lecturer \\ V.N. Karazin Kharkiv National University \\ Svobody sq., 6, Kharkiv, Ukraine, 61022 \\ E-mail:anna.perepelytsia@karazin.ua \\ ORCID: https://orcid.org/0000-0002-2306-7975 \\ Yuliia Yurchenko \\ Student \\ V.N. Karazin Kharkiv National University \\ Svobody sq., 6, Kharkiv, Ukraine, 61022 \\ E-mail:julia22410@gmail.com \\ ORCID: https://orcid.org/0000-0001-9435-9716
}

\begin{abstract}
The leisure and hospitality industry is one of the driving forces of the global economy. The widespread adoption of new technologies in this industry over recent years has fundamentally reshaped the way in which services are provided and received. In this paper, some of the state-of-the-art technologies are explored that are currently employed in the hospitality industry and how they are improving guest experiences and changing the hospitality service platform. We also envision some potential future hospitality services we can expect as the Internet of things (loT) technology keeps growing. The subject of the research is the activity of hotel enterprises. The purpose of the research is the penetration of IT in the management of the hotel business. As a result the current state of IT use in hotel complexes has been investigated and practical experience in using IT in the hospitality industry has been considered.

According to the World Tourism Organization (WTO), today there are more than 16 million hotels in the world, with $20 \%$ of them belong to hotel chains. The largest number of hotel enterprises is concentrated in the countries of Europe and North America, which accounts for $72 \%$ of the total hotel base.

An interesting note that over the last 10 years other types of businesses have begin to recognize the unique combination of skills which hospitality students possess - the combination of sound business and management along with a service orientation. Therefore, other industries have begun to recruit hospitality graduates including health care and retail.

This is particularly exciting time to be associated with the industry given the ample career opportunities, the economy, new developments, emerging markets, internationalization of companies ad concepts, etc.

The prevailing philosophy in hospitality education is that the best way to the top is through a strategic combination of education and experience.

The outlook for the industry is very positive but there are several trends/factors that are affecting how the industry operates and the products and services that are offered to the customers.

Key words: Hospitality industry, information technologies, hotel management, information systems, innovations, hotel technologies
\end{abstract}

Problem formulation. The intense competition in today's business environment means that tourism and hospitality businesses have to work hard to maintain and develop their competitiveness. The success of a business, to certain extent, depends on its ability to acquire and utilize updated information to assist its management and marketing processes.

Tourism and hospitality are social phenomena, and the industries associated with them are largely application oriented. Therefore, the hotel business should be equipped with numbers of information technologies which have recently drawn the attention of tourism and hospitality researchers worldwide, who have disseminated their findings in research journals.

Unfortunately, this field of research has recently faced the difficulty of following the modern direction into an area connected with recent IT trends. What is more, such a situation causes troubles with financial ground and the leaders of hotel companies might lose their money without proper knowledge.

It is advantageous for hospitality managers to be aware of the recent changes in IT and their relationship with customer service.
Analysis of recent studies and published works. The study of IT in hospitable sphere is becoming increasingly prominent with the expansion of service sector worldwide. At present, there is no standard list of research journals in the field. The list of 57 journals in the article of Arendt, Ravichandran, and Brown, Hospitality and tourism journal matrix Journal of Hospitality \& Tourism Education, appears to be the most up-to-date and comprehensive.

The basic ideas. Once long ago, hotels, motels and other hospitality businesses occupied a fairly simple space in people's lives - they were a place for guests to lay their heads away from home. But anyone who's spent time in the hospitality industry in the last several years knows that the role of technology in hospitality businesses has drastically expanded.

In many cases, they're becoming hubs of activity unto themselves. Most of this activity relies directly or indirectly on technology, making IT more important to hotel operations and the guest experience than ever before.

Domestic and international tourism has seen several years of steady growth. The revenue 
generated from accommodation, food and beverage, and other services provided to this large flux of travelers, has propelled the leisure and hospitality industry to become a key driver of the global economy. For sustained growth of this industry, experts in the field argue for major improvements in the type and quality of hospitality services to adapt to the changing consumption and travel behaviors of the evolving customer base. The hospitality industry is adopting technology at breakneck speed.

The hotel business is facing cutthroat competition. Thus, Information technology in the Hotel industry is more important than ever today.

Each of the Hotel brands has to come up with a unique pitch and specialized services which can cater and appeal to customers in a range of ways.

In the eyes of most consumers, most services offered by hotels are relatively the same so hotels must strive to find a competitive edge as a way of standing out from the crowd. As a means of attracting repeat business, a key weapon in most hotels' arsenal is technology.
Hotels can attract a new breed of customers by integrating technology in all aspects. However, technology is in an invariable state of flux and is constantly unlocking new opportunities aimed at improving customer satisfaction and boosting internal efficiency.

As such, although the technology is there, the hotels themselves have their task cut out when it comes to leveraging technology to beat the competition.

So how does technology make a difference when it comes to beating the competition? Simply put, technology makes life easier for many guests, and here is how.

As the Internet system grows and spreads into different parts of everyday life, we can expect a future where every physical device that we use analyzes our data and automatically provides us services. The hospitality industry is inclined to follow this growing trend to offer new types of services to its quests as well as to enact cost saving measures. Figure 1 shows examples of Internet of things devices the different service categories they can be employed for.

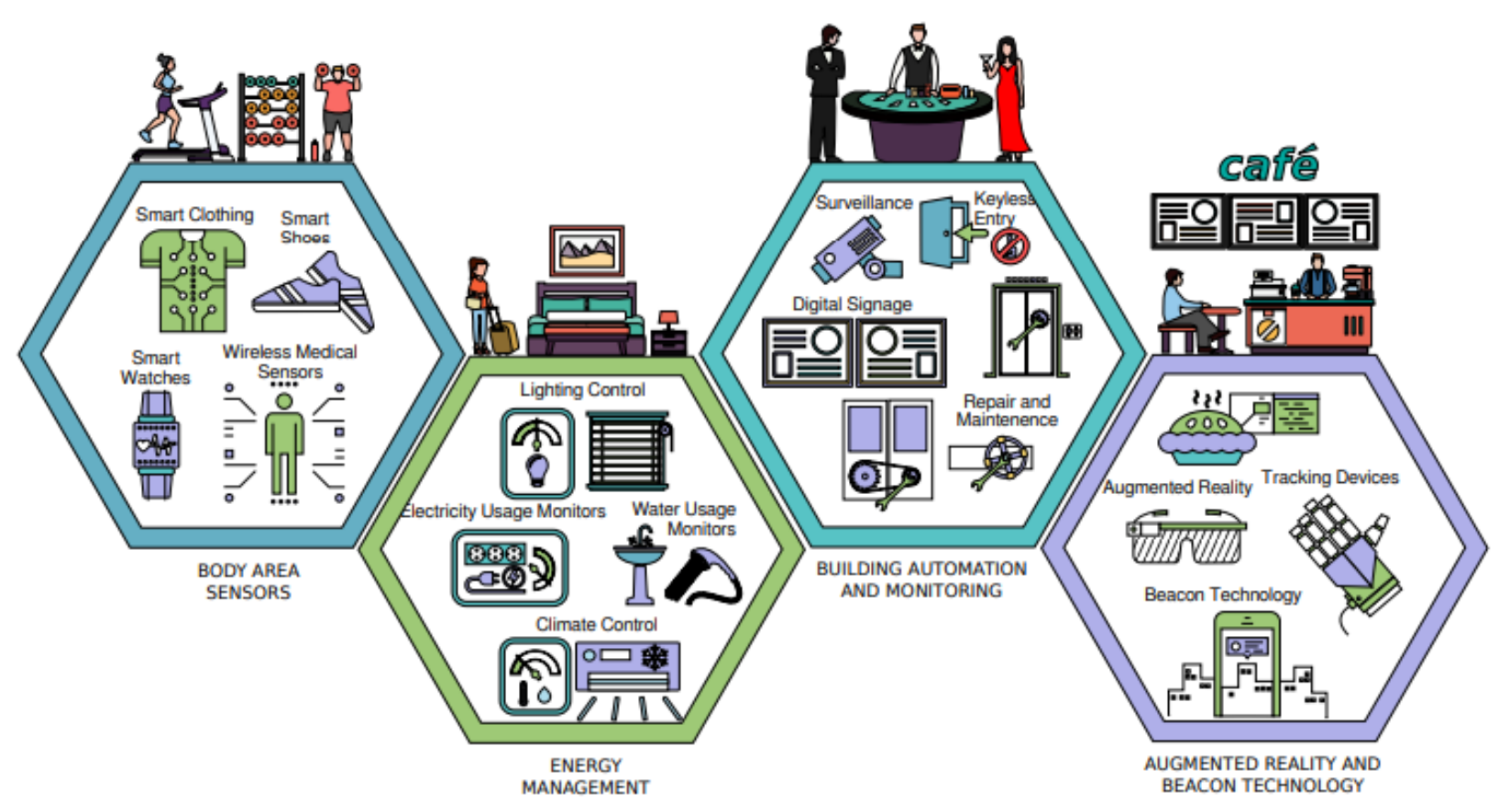

Fig. 1. A variety of future services in the hotel industry

Source: Created by the author according to the data [7, p.1-15]

\section{Body Area Sensors}

Sales of devices such as smartphones, smartwatches, etc., are soaring and smart technology is beginning to be included in other wearable forms like smart clothing, smart shoes, etc. These devices gather user data like body temperature, heart rate, location, fitness activities, etc. Wireless medical sensor technology further expands the scope of data collection by providing detailed data about organs and systems within the body. With proper analysis of data gathered through body area sensor networks, Hospitality Service Providers (HSP) can offer a host of 198 new services to their guests such as, automatic adjustment of in-room temperature based on body temperature, adjustment in-room lighting based on a guest's sleep-cycle, etc. [6, pp.135-136].

2. Energy Management

HSP can admit several cost-saving measures in the management of on-property energy consumption by leveraging technology. These measures are particular beneficial in achieving "green" operation of onproperty systems. Some hotel properties include smart lighting and temperature control systems as well as use of low power devices like LED lights 
[8, pp.1-13] [12]. IoT technologies can significantly expand the scope of energy-saving systems.

\section{Building Automation and Monitoring}

Both guests and service providers benefit from building automation and monitoring. New hospitality services such as keyless entry services, digital concierge, etc. which will be brought about by developments in IoT - enabled systems will greatly improve guest satisfaction. These services are not only appealing for technophile users, but, they can be specially helpful for guests with disabilities. Building automation and monitoring also leads to better operational and managerial efficiency for HSP [5].

4. Augmented Reality and Beacon Technology

HSP are coming up with new ways to incorporate augmented reality and beacon technology into their on-property systems [6, pp.135-136; 2]. This technology can be used to provide guests with services such as digitally guided tours, previews of inroom environment (e.g., décor, facilities and amenities, etc.), immediate translation services for signs and other written materials, interactive restaurant menus with dish previews. These services can be bundled as part in-house loyalty applications [1, pp.133-135].

\section{Smart room keys}

It's fascinating that a function as simple as a door key could undergo so much evolution. But the tool that once started as a carefully shaped piece of metal quickly turned into electronic key cards, and is set to shed its physical form altogether [3].

The next evolution of the hotel key transforms it into data on a guest's mobile device. Hotels will increasingly install smart room access systems that allow guests to unlock their doors by simply swiping their phones across a keyless pad on the door. Another innovative way to offer a keyless experience is through fingerprint-activated room entry systems and retina scanning devices. Retina scanning is even more accurate and secure than fingerprint scans [9].

\section{Guest Apps}

The vision of the connected guest entails nearly every aspect of the guest experience. Something as complex as that needs a single hub from which to operate-and guest apps for personal mobile devices are the natural place to host all of these functions. A smartly designed guest app combines everything from deal notifications to hotel services to loyalty programs. If you see a guest used the group rate for a conference, you could use the app to electronically send your guest the event itinerary, complete with a map of meeting spaces where sessions will be held.

Most major hotels have some element of this picture in play already, and they're adding capabilities every day. Some of the major flags are closer, but much of the technology and integration is still in development [10].

7. Battle For Bandwidth

A smart phone.A laptop.A tablet.An e-reader. It seems like hospitality guests bring every Internet bandwidth-sucking device they own when they travel.
And whether they're travelling for business or pleasure, you can bet you're going to hear about it if they can't connect as quickly and reliably as they're used to at home.

But a hotel is not a home. You have to multiply those data needs by dozens, if not hundreds, of guests-possibly thousands if you land a big conference. It's a huge strain and one that many of the best hospitality brands are working on. Whatever your solution, rest assured, the demand for bandwidth at hotels is only going to grow [10].

\section{Location Based Services}

Much of this technology is in its infancy, but the implications are huge. Being able to understand where hotel staff and guests are located at any given time creates all kinds of opportunities to improve the guest experience-from being able to deliver services to guests while freeing them from their rooms to helping event staff operate more efficiently to turning over rooms more quickly and beyond.

Some employee location-based features are already available using SIP-DECT, but this is just the beginning. This is a category to keep an eye on [10].

\section{SIP-DECT}

Already popular in the hospitality space and other industries in Europe, SIP-DECT is a mobility-enabling alternative to VoWLAN and radio-based networks that are starting to get attention in North America.

Many SIP-DECT setups bring the kind of features usually found on a fixed network to mobile workers all over your hotel or campus without tethering them down to specific locations. Since hotel service staff, like housekeeping, valet, concierge, and event staff are often on the go, SIP-DECTa natural fit for hoteliers [10].

With relatively low cost compared to the alternatives, ease of deployment and quality, predictable voice quality, SIP-DECT is poised to take off in a big way.

10. Check-in via guests' smartphones

It'll make life easier for everybody. Guests can check into their room on their phones, grab the keys from the check-in counter, and head straight to their room without having to stand there with their bags, staring off into space while the receptionist taps away at a keyboard.

Mobile check-in is also a good way to get customers using your app, which allows you to promote your hotel and make it easier for your customers to connect with you when they want [3].

The technology certainly exists, and people seem to really want it: data firm Zebra Technologies published a study that found that $68 \%$ of guests want to speed up the check-in process using their smartphones.

11. Trecking of loyal guests

The Zebra Technologies study also found that $74 \%$ of hotel guests would like some sort of customized offer or a loyalty program.

Through information technology, it is possible to keep track of hotel's guest preferences and log special 
requests, room service orders, and other data so that when they check-in again down the line, they can be surprised with a thoughtful gesture, such as a fresh cup of their favorite brand of coffee [3].

"As competition for travelers' mindshare intensifies, hospitality managers have sharpened their focus on differentiating the guest stay via unique and personalized experiences in a bid to strengthen loyalty and encourage repeat visits," the report states. "For guests, feeling catered to nowadays means not only hassle-free booking, but also service and offers that reflect individualized messaging and marketing based on their personal profile, activities and preferences."

12. Artificial Intelligence

Take Hilton Worldwide, for example, which unveiled an AI-based concierge that they dubbed
"Connie" in 2016. The robot uses the power of IBM's supercomputer Watson, and it is able to help guests with tourist attractions, dining recommendations, and hotel features (Fig.2).

"Currently stationed near reception at the Hilton McLean in Virginia, Connie is learning to interact with guests and respond to their questions in a friendly and informative manner». Hilton, the general manager of the hotel, says that the more guests interact with Connie, the more it learns, adapts, and improves its recommendations.

This kind of technology can remain too costly for some years/. But as hotel chains start to use it more frequently, the cost will come down, and these AI options will be available to independent and boutique hotels in the coming years [11].

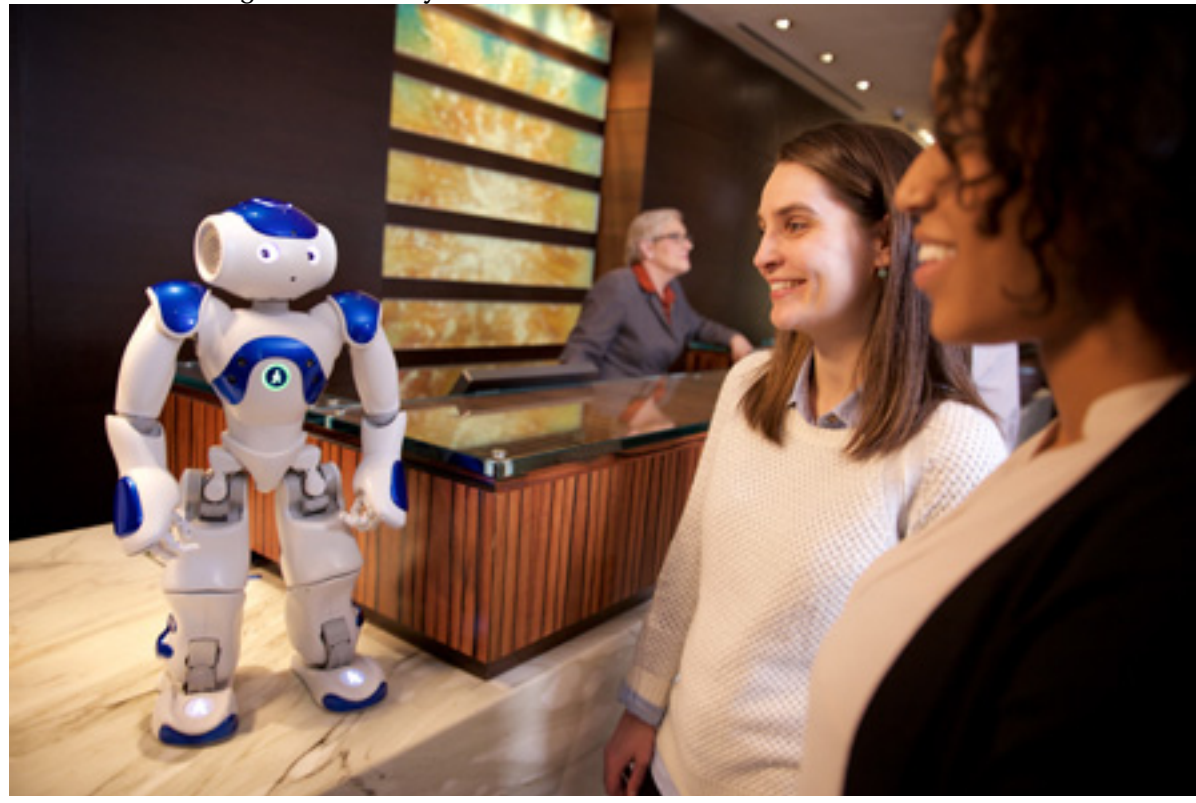

Fig. 2.Connie, via Hilton Worldwide

\section{NFC Technology}

Near field communication (NFC) technology is the next-generation short-range high frequency wireless communication technology that gives users the ability to exchange data between devices. Communication between NFC devices can transfer data at up to 424 $\mathrm{kbits} / \mathrm{second}$ and the communication is enabled when two devices touch each other, which makes mobile payments (by touching the smart phone to a credit card) an instant, secure process [9].

Besides payments and an easier way to gain entry to hotel rooms, NFC technology can also be used to personalize a guest's experience at a hotel or resort. For example, advertising can be targeted based on gender and age (so if a child walks by a digital sign in the lobby, the advertisement can change to promote a local theme park or the hotel's kids club) and this technology could also be used to track loyalty points from a guest's use of the conference facilities or room service. This opens many doors for hotels who want to offer a more personalized experience at their establishment.

\section{Robots and infrared sensors}

Some hotels are already offering more futuristic experiences, with robots delivering any items ordered through room service to a guest's door. A boutique hotel that is nestled between Apple's headquarters and other tech companies, called Aloft Cupertino, has a robot butler called Botlr that is able to move between the various floors of the hotel in order to take items such as toothbrushes, chargers and snacks to guests. These types of digital systems not only make it easy for hotel staff to deliver items to guests, but it also offers a forward-facing digital experience to people who stay at the hotel.

Infrared scanners are now also used to minimize disruptions relating to housekeeping (which is a common complaint from customers). Instead of hanging a 'Do Not Disturb' sign on doors or having cleaning staff wake up traveling guests with knocks and phone calls, hotel staff can take a more innovative approach by using infrared scanners that will detect body heat within a room and tell cleaning staff that 
they should rather come back later if the room is currently occupied [9].

15. Predictive Analytic

The use of predictive analytics is one of the most important ways to increase hotel revenue.

Wouldn't it be great if tailor-made updates could be sent via emails, SMSs to customers based on their preferences? For e.g.: A spa coupon can be targeted particularly for guests who have used this service in your hotel earlier. It empowers hoteliers to make informed decisions by understanding what kind of problems they may face tomorrow.

Investing in the right kind of technology in hospitality industry will help you to be prepared and improve a hotel's management in all aspects. For e.g. any hotel that includes multiple POS outlets needs to focus on providing a personalized service to their guests. This will ensure hoteliers have a higher chance of getting repeat customers. Any data that helps to understand a guests' preference is considered to be the best use of data. Guests are interested in knowing about the choices relevant to them rather than looking at a plethora of choices [4].

Technology will be helpful to suggest which guest is suitable for any specific promotion, offers, and discounts. Usage of this information gives a holistic view into the customer's requirements

Conclusion. Tourism and hospitality are social phenomena, and the industries associated with them are largely application oriented. Researchers in this field have conducted, and will continue to conduct, research that generates innovative knowledge that will benefit these industries and ultimately society. As investment in and the adoption of IT are now indispensable components of the tourism and hospitality business, IT serves as a tool for both enabling and inducing change.

\section{СУЧАСНІ ТЕНДЕНЦІї ГОТЕЛЬНИХ ТЕХНОЛОГІЙ ДЛЯ СФЕРИ ГОСТИННОСТІ}

Перепелиця Анна Сергіївна, старший викладач, Харківський національний університет імені В. Н. Каразіна, м. Свободи, 6, м. Харків, Україна, 61022, e-mail: anna.perepelytsia@karazin.ua, ORCID:https://orcid.org/0000-0002-2306-7975

Юрченко Юлія Анатоліївна, студент, Харківський національний університет імені В. Н. Каразіна, м. Свободи, 6, м. Харків, Україна, 61022, e-mail:julia22410@gmail.com, ORCID : https://orcid.org/0000-0001-9435-9716

Індустрія дозвілля та гостинності є однією з рушійних сил світової економіки. Широке застосування нових технологій у цій галузі впродовж останніх років кардинально змінило спосіб надання та отримання послуг. У даній роботі розглядаються сучасні технології, які в даний час використовуються в індустрії гостинності та як вони вдосконалюють враження від гостя та змінюють платформу обслуговування у готелях. Також передбачені деякі можливі майбутні служби гостинності, які ми можемо очікувати, оскільки технологія Інтернет речей ( IP ) продовжує зростати. Предметом дослідження є діяльність готельних підприємств. Метою дослідження є проникнення IT в управління готельним бізнесом. В результаті досліджено поточний стан використання IT в готельних комплексах і розглянуто практичний досвід використання IT в індустрії гостинності.

За даними Всесвітньої туристичноїорганізації (ВТО), сьогодні в світі діють більше 16 млн готелів, причому $20 \%$ з них відносяться до готельних мереж. Найбільше число готельних підприємств зосереджено в країнах Європи та Північної Америки, на частку яких припадає $72 \%$ всієї готельної бази. Цікаво зазначити, що протягом останніх 10 років інші види бізнесу починають визнавати унікальну комбінацію навичок, якими володіють учні гостинності, - поєднання здорового бізнесу та управління, а також сервісної орієнтації. Це особливо хвилюючий час для асоціації з галуззю з огляду на широкі можливості кар'єрного росту, економіку, нові розробки, ринки, що розвиваються, інтернаціоналізація концепцій компаній та ін.

Переважна фрілософія в освіті гостинності полягає в тому, що найкращий шлях до вершини - це стратегічне поєднання освіти та досвіду. Перспективи розвитку галузі є дуже позитивними, але існує кілька тенденцій / факторів, які впливають на роботу галузі та продукти та послуги, які пропонуються клієнтам.

Ключові слова: Індустрія гостинності, інформаційні технології, готельний менеджмент, інформаційні системи, інновації, готельні технології, світова економіка, готельні підприємства.

\section{СОВРЕМЕННЫЕ ТЕНДЕЦИИ ГОСТИНИЧНЫХ ТЕХНОЛОГИЙ ДЛЯ ИНДУСТРИИ ГОСТЕПРИИМСТВА}

Перепелица Анна Сергеевна, старший преподаватель, Харьковский национальный университет имени В. Н. Каразина, пл. Свободы, 6, г. Харьков, Украина, 61022, e-mail: anna.perepelytsia@karazin.ua, ORCID: https://orcid.org/0000-0002-2306-7975 Юрченко Юлия Анатольевна, студент, Харьковский национальный университет имени В. Н. Каразина, пл. Свободы, 6, г. Харьков, Украина, 61022, e-mail:julia22410@gmail.com, ORCID : https://orcid.org/0000-0001-9435-9716

Индустрия отдыха и гостеприимства является одной из движущих сил мировой экономики. Широкое внедрение новых технологий в данной отрасли за последние годы изменило способ предоставления и получения услуг. В этой работе изучаются некоторые из современных технологий, которые в настоящее время используются в индустрии гостеприимства , и как они улучшают опыт, приобретенный гостями, и меняют платформу обслуживания в гостиницах. Более того, рассмотрены потенциальные услуги сферы гостеприимства, которые мы можем ожидать, поскольку технология Интернета продолжает увеличиваться. Предметом исследования является деятельность гостиничных предприятий. Целью исследования является внедрение ИТ в управление гостиничным бизнесом. В результате исследовано текущее состояние использования ИТ в гостиничных комплексах и рассмотрен практический опыт использования ИТ в индустрии гостеприимства.

По данным Всемирной туристической организации (ВТО), сегодня в мире действуют более 16 млн гостиниц, причем 20\% из них относятся к гостиничным сетям. Наибольшее число гостиничных предприятий сосредоточено в странах Европы и Северной Америки, на долю которых приходится $72 \%$ всей гостиничной базы. Интересный факт, что в течение последних 10 лет другие типы предприятий начали осознавать уникальное сочетание навыков, которыми обладают студенты гостеприимства, сочетание разумного бизнеса и управления вместе с ориентацией на обслуживание. Это особенно интересное время, чтобы быть связанным с отраслью, учитывая широкие возможности для карьерного роста, экономику, новые разработки, развивающиеся рынки, интернационализацию рекламных концепций компаний и др.

Преобладающая философия в гостиничном образовании заключается в том, что лучший путь к вершине - это стратегическое сочетание образования и опыта. Перспективы для отрасли очень позитивны, но есть несколько тенденций / факторов, которые влияют на работу отрасли, а также на продукты и услуги, предлагаемые клиентам.

Ключевые слова: индустрия гостеприимства, информационные технологии, гостиничный менеджмент, информационные системы, инновации, гостиничные технологии, мировая экономика, гостиничные предприятия. 


\section{References}

1. Perey. C. (2015). Open and interoperable augmented reality and the ieee. IEEE Consumer ElectronicS Magazine, 4(133 - 135.)Vol. 4.DOI:10.1109/MCE.2015.2463432

2. Hospitality Technology. Smarter Hotels \& Restaurants. (2015). How hotels are using beacons and augmented reality.Retrieved from https://hospitalitytech.com/how-hotels-are-using-beacons-and-augmented-reality

3. Capterra. (2018). Information Technology in the Hotel Industry: 5 Things You Didn't Know. Retrieved from https://blog.capterra.com/information-technology-in-the-hotel-industry-5-things-you-didnt-know/

4. HOTELOGICX. Smart hoteliering. (2018).New and Emerging Hospitality Technology Trends. Retrieved from https://www.hotelogix.com/blog/2018/02/07/top-hospitality-industry-technology-trends-2018/

5. Vermesan, O., \&Friess, P. (2014).Internet of Things Applications.From Research and Innovation to Market Deployment. River Publishers Series in Communication.

6. Tussyadiah, P., Jung, T. H., \& C. Perey, tom Dieck.(2015).Open and interoperable augmented reality and the ieee.4 (135-136),Vol. 4. DOI: https://doi.org/10.1109/mce.2015.2463432

7. Journal of Travel Research.(2017). $(1-15)$.

8. Hsiao, T.-Y., Chuang, C.-M., \& Huang, L. (2018).The contents, determinants, and strategic procedure for implementing suitable green activities in star hotels. International Journal of Hospitality Management. Vol. 69, 1 13.DOI:https://doi.org/10.1016/j.ijhm.2017.10.005

9. Aurecon. (n.d.) Technology in the hospitality industry exploring the very latest trends. Retrieved from https://www.aurecongroup.com/thinking/insights/aurecons-successful-hotels/technology-in-thehospitality-industry-exploring-the-very-latest-trends

10. Mitel. Powering connections. (n.d.). TOP 10 COMMUNICATION TRENDS IN HOTEL TECHNOLOGY FOR 2018. Retrieved from https://www.mitel.com/blog/top-10-communication-trends-in-hotel-technology-for2018

11. Babenko, V., Romanenkov, Yu., Yakymova, L., Nakisko, A. (2017). Development of the model of minimax adaptive management of innovative processes at an enterprise with consideration of risks. Eastern-European Journal of Enterprise Technologies, 5, 4 (89), pp. 49-56. DOI: https://doi.org/10.15587/1729-4061.2017.112076

12. Capterra. (2018). Trends to Watch: 4 Emerging Hotel Management Technologies. Retrieved from https://blog.capterra.com/emerging-hotel-management-technologies/

13. Babenko, V.A., Shorikov, A.F. (2012). Optimization of software management of innovative technologies at agricultural enterprises. Modern problems of economics, management and marketing: materials of the XVIII International scientific and practical. conf. (June 1, 2, 2012, Nizhny Tagil). Nizhny Tagil: NTI (branch) of Ural Federal University, pp. 34-37. [in Russia]

14. Lee,W.-H.,\& Cheng,C.-C.(2018).Less is more: A new insight for measuring service quality of green hotels.International Journal of Hospitality $\quad$ Management.Vol. $\quad 68, \quad 32 \quad-\quad 40 . \quad$ DOI: https://doi.org/10.1016/j.ijhm.2017.09.005 